\title{
HUBUNGAN PERSEPSI LINGKUNGAN PEMBELAJARAN DENGAN STRATEGI PEMBELAJARAN MAHASISWA PROGRAM STUDI PENDIDIKAN DOKTER UNIVERSTAS JAMBI
}

\author{
Nyimas Natasha Ayu Shafira, Anwar Jusuf, Setyawati Budiningsih \\ Fakultas Kedokteran dan Ilmu Kesehatan, Universitas Jambi \\ Fakultas Kedokteran dan IImu Kesehatan, Universitas Indonesia
}

\begin{abstract}
Background: Students' perceptions toward learning environment may influence the use of students' learning strategies. In medical education, the students are expected to implement deep approach. Therefore, students' learning environment should be able to direct the students to learning by using deep approach.

Aim: The purpose of the research was to investigate the relationship between students' perception about learning environment, students' l earning strategies, among medical student in Jambi Medical School (UNJA)

Methods: This research employs cross sectional design from April to June 2012. The samples were 198 respondents who were students in semester 2, 4 and 6. The date of the perception about the learning environment and learning strategies was adopt from questionnaires from Dundee Ready Educational Environment Measure (DREEM) and The Revised two Factor study process Questionnaire (R-2F-SPQ).

Results and Discussion: The study showed that 80 percent of the students have positive perception regarding learning environment in UNJA. More than half of the students applied deep approach. There was significant relationship between students' perceptions about learning environment with learning strategies used by the students $(p=0,001)$. There was a tendency that better students' perception toward learning environment made students prefer deep approach.

Conclusion: There is significant relationship between students' perceptions about learning environment with learning strategies used by the medical students of PSPD Jambi.
\end{abstract}

Keywords: perception, learning environment, learning strategies, medical student.

\section{ABSTRAK}

Latar Belakang: Persepsi mahasiswa terhadap lingkungan pembelajaran dapat mempengaruhi penggunaan strategi pembelajaran mahasiswa. Dalam pendidikan kedokteran mahasiswa diharapkan dapat menerapkan strategi pembelajaran pendekatan mendalam. Oleh karena itu lingkungan pembelajaran mahasiswa harus dapat mengarahkan mahasiswa pada pembelajaran dengan menggunakan strategi pembelajaran pendekatan mendalam.

Tujuan: Tujuan penelitian ini adalah untuk mengetahui persepsi mahasiswa terhadap lingkungan pembelajaran dan strategi pembelajaran mahasiswa, pada mahasiswa Universitas Jambi (PSPD UNJA).

Metode: Penelitian cross sectional dilaksanakan pada bulan April-Juni 2012 dan melibatkan 198 responden mahasiswa semester 2, 4 dan 6. Data persepsi terhadap lingkungan pembelajaran dan strategi pembelajaran didapat dari kuesioner Dundee Ready Educational Environment Measure (DREEM) dan The Revised two Factor study process Questionaire (R2F-SPQ).

Hasil dan Pembahasan: Penelitian ini menunjukkan 80\% mahasiswa memiliki persepsi positif terhadap lingkungan pembelajaran UNJA. Lebih dari 50\% mahasiswa PSPD UNJA menerapkan strategi pembelajaran pendekatan mendalam. Terdapat hubungan yang bermakna antara persepsi mahasiswa terhadap lingkungan pembelajaran dengan strategi

Korespondensi: nyimas_natasha@yahoo.com 
pembelajaran yang digunakan $(p=0,001)$, semakin baik persepsi mahasiswa terhadap lingkungan pembelajaran, maka mahasiswa lebih banyak menggunakan pendekatan mendalam.

Kesimpulan: Pada penelitian ini disimpulkan ada hubungan yang bermakna antara persepsi mahasiswa terhadap lingkungan pembelajaran dengan strategi pembelajaran yang digunakan mahasiswa.

Kata Kunci: Persepsi, lingkungan pembelajaran, strategi pembelajaran, mahasiswa kedokteran.

\section{PENDAHULUAN}

Lingkungan pembelajaran merupakan hasil manifestasi, operasionalisasi dan konseptualisasi dari suatu kurikulum yang melibatkan berbagai faktor dan aspek suatu insititusi yang kemudian menjadi karakteristik lingkungan dan mempunyai pengaruh terhadap keseluruhan program pendidikan. ${ }^{1}$ Strategi pembelajaran merupakan representasi dari persepsi mahasiswa tentang suatu lingkungan pem-belajaran. ${ }^{2,3,4}$ Secara umum, strategi pembelajaran dapat dibagi menjadi dua kategori yaitu deep approach (pendekatan mendalam) dan surface approach (pendekatan dangkal). ${ }^{5}$ Pendekatan mendalam ditandai dengan keinginan untuk memahami materi sehingga menghasilkan kualitas hasil belajar yang tinggi. Sebaliknya, pendekatan dangkal ditandai dengan keinginan untuk mencapai hasil minimal dengan usaha minimal sehingga menghasilkan kualitas hasil belajar yang rendah. ${ }^{5,6}$ Dalam pendidikan kedokteran mahasiswa diharapkan untuk dapat menerapkan pendekatan mendalam. Oleh karena itu lingkungan pembelajaran mahasiswa harus dapat mengarahkan mahasiswa pada pembelajaran dengan menggunakan pendekatan mendalam. ${ }^{7}$

Persepsi mahasiswa terhadap lingkungan pembelajaran dapat mempengaruhi penggunaan strategi pembelajaran mahasiswa. Faktor-faktor yang terdapat pada lingkungan pembelajaran yang dapat mendorong mahasiswa menggunakan pendekatan dalam antara lain adalah penggunaan metode pengajaran dan evaluasi yang menimbulkan keterikatan dengan materi pembelajaran yang bersifat aktif dan jangka panjang, tujuan pembelajaran yang jelas, minat pada latar belakang pengetahuan yang terdapat pada materi pembelajaran. ${ }^{3,8}$

Tujuan penelitian ini adalah untuk mengetahui persepsi mahasiswa terhadap lingkungan pembelajaran, strategi pembelajaran mahasiswa, serta untuk mengetahui adanya hubungan antara persepsi mahasiswa terhadap lingkungan pembelajaran dengan strategi pembelajaran mahasiswa.

\section{METODE}

Penelitian cross sectional dilaksanakan pada mahasiswa kedokteran Universitas Jambi (UNJA) pada bulan AprilJuni 2012 dan melibatkan 265 responden mahasiswa semester 2, 4 dan 6. Data persepsi terhadap lingkungan pembelajaran dan strategi pembelajaran didapat dari kuesioner Dundee Ready Educational Environment Measure (DREEM) dan The Revise two Factor study process Questionaire (R-2F-SPQ). 16 Data penelitian yang diperoleh dianalisis secara univariat dan bivariat dengan menggunakan program SPSS versi $11 .^{5}$

\section{HASIL DAN PEMBAHASAN}

\section{Karakteristik Subjek Penelitian}

Dari total populasi mahasiswa semester 2, 4 dan 6, mahasiswa yang bersedia mengisi kuesioner sebesar 198 (response rate 92\%). Subjek penelitian terbanyak adalah berjenis kelamin perempuan yaitu sebanyak $75,8 \%$. Berdasarkan tingkat akademik, jumlah subjek penelitian terbanyak adalah mahasiswa semester 2 (tabel 1).

Tabel 1. Karakteristik Subjek Penelitian

\begin{tabular}{ccc} 
Karakteristik & $\mathbf{n}=\mathbf{1 9 8}$ & $\%$ \\
Jenis kelamin & & \\
Laki -laki & 48 & 24,2 \\
Perempuan & 150 & 75,8 \\
\hline Semester & & \\
Semester 2 & 81 & 40,9 \\
Semester 4 & 47 & 23,7 \\
Semester 6 & 70 & 35,4 \\
\hline
\end{tabular}




\section{Persepsi Mahasiswa terhadap Lingkungan Pembelajaran di PSPD UNJA}

Hampir sebagian besar mahasiswa $(85,9 \%)$ memiliki persepsi positif (skor 101-150) terhadap lingkungan pembelajarannya (tabel 2). Masalah dalam lingkungan pembelajaran hanya dirasakan oleh 5,6\% mahasiswa.

Tabel 2. Persepsi mahasiswa kedokteran terhadap lingkungan pembelajaran Universitas Jambi

\begin{tabular}{lcc} 
Persepsi terhadap lingkungan pembelajaran & $\mathbf{n}=198$ & $\%$ \\
Terdapat masalah (51-100) & 11 & 5,6 \\
Lcbih banyak hal positif daripada negatif (101-150) & 170 & 85,9 \\
Sangat memuaskan (151-200) & 17 & 8,6 \\
\hline
\end{tabular}

Tabel 3 menunjukkan bahwa kelima kategori persepsi terhadap lingkungan pembelajaran, sebagian besar $(74,7$ $-86,4 \%)$ menyatakan hasil positif atau baik. Jumlah mahasiswa yang mempunyai persepsi kurang atau negatif terhadap kelima kategori berkisar antara 4,5 - 21,2\%.

Tabel 3. Kategori persepsi mahasiswa terhadap lingkungan pembelajaran

\begin{tabular}{lrr} 
Kategori & $=198$ & $\%$ \\
\hline Persepsi terhadap proses pembelajaran & & \\
Negatif (13-24) & 12 & 6,1 \\
Positif (25-36) & 161 & 81,3 \\
Sangat baik (37-48) & 25 & 12,6 \\
Pcrscpsi tcrhadap Pcngajar & & \\
Sangat buruk (0-11) & 1 & 0,5 \\
$\quad$ Memerlukan perhatian (12-22) & 9 & 4,5 \\
Baik (23-33) & 150 & 75,8 \\
Sangat baik (34-44) & 38 & 19,2 \\
Persepsi terhadap Pencapaian akademik pribadi & & \\
Negatif (9-16) & 11 & 5,6 \\
Positif (17-24) & 171 & 86,4 \\
Percaya diri (25-32) & 16 & 8,1 \\
Persepsi terhadap Atmosfer akademik & & \\
Mcmcrlukan pcrubahan (13-24) & 42 & 21,2 \\
Positif (25-36) & 148 & 74,7 \\
Baik (37-48) & 8 & 4,0 \\
Persepsi terhadap Kehidupan sosial & & \\
Bukan tempat yang baik (8-14) & 23 & 11,6 \\
Cukup baik (15-21) & 161 & 81,3 \\
Sangat baik (22-28) & 14 & 7,1 \\
\hline
\end{tabular}

\section{Gambaran Jawaban Responden terhadap Kuesioner DREEM}

Tabel 4. Pada kategori persepsi terhadap proses pembelajaran, jumlah mahasiswa yang memberikan jawaban negatif paling banyak ditemukan pada pernyataan "kegiatan belajar mengajar terlalu menekankan pada pembelajaran mengenai informasi faktual" sebanyak 80,8\%. Pada kategori persepsi terhadap staf pengajar, jawaban negatif paling banyak ditemukan pada pernyataan "staf pengajar menunjukkan kemarahan di dalam kelas" (51\%). 
Jawaban negatif pada kategori persepsi terhadap pencapaian akademik pribadi paling banyak ditemukan pada pernyataan "kemampuan pemecahan masalah berkembang dengan baik disini" (41,9\%).

Untuk kategori persepsi terhadap atmosfer akademik jawaban negatif paling banyak ditemukan pada pernyataan "jadwal kegiatan belajar mengajar tersusun dengan baik" sebanyak 88,4\%. Dan pada kategori persepsi terhadap kehidupan sosial, jawaban negatif paling banyak ditemukan pada pernyataan "terdapat sistem dukungan yang baik bagi mahasiswa yang mengalami stres" sebanyak $83,4 \%$.

Tabel 4. Jawaban negatif terbanyak pada kategori persepsi mahasiswa terhadap lingkungan pembelajaran

\begin{tabular}{lcc}
\multicolumn{1}{c}{ Pernyataan } & $\begin{array}{c}\text { Positif } \\
\%\end{array}$ & $\begin{array}{c}\text { Negatif } \\
\%\end{array}$ \\
\hline $\begin{array}{l}\text { Kategori persepsi terhadap proses pembelajaran } \\
\text { Kegiatan belajar mengajar terlalu menekankan pada pembelajaran mengenai } \\
\text { informasi faktual }\end{array}$ & 19,2 & 80,8 \\
$\begin{array}{l}\text { Kategori persepsi terhadap staf pengajar } \\
\text { Staf pengajar menunjukkan kemarahan dalam kelas }\end{array}$ & 49 & 51 \\
Kategori persepsi terhadap pencapaian akademik pribadi & & \\
Kemampuan pemecahan masalah berkembang dengan baik di sini & 51,9 \\
Kategori persepsi terhadap atmosfer akademik & 11,6 & 88,4 \\
Jadwal kegiatan belajar mengajar tersusun dengan baik & 19,6 & 83,4 \\
Kategori persepsi terhadap kehidupan sosial & & \\
Terdapat sistem dukungan yang baik bagi mahasiswa yang mengalami stres & & \\
\hline
\end{tabular}

\section{Strategi Pembelajaran Mahasiswa PSPD UNJA}

Pada tabel 5 terlihat lebih dari lima puluh persen mahasiswa PSPD UNJA menggunakan pendekatan mendalam dan 36,9\% mahasiswa menggunakan pendekatan dangkal dalam pembelajarannya.

Tabel 5. Strategi Pembelajaran mahasiswa PSPD UNJA

\begin{tabular}{lcc} 
Strategi Pembelajaran & $\mathrm{n}=198$ & $\%$ \\
\hline Pendekatan Dangkal & 73 & 36,9 \\
Pendekatan Mendalam & 125 & 63,1 \\
\hline
\end{tabular}

Hubungan antara Persepsi Mahasiswa terhadap Lingkungan Pembelajaran dengan Strategi Pembelajaran Mahasiswa PSPD UNJA

Berdasarkan tabel 6, didapatkan nilai $p=0,001(p<0,05)$. Hal ini menunjukkan bahwa ada hubungan antara persepsi lingkungan pembelajaran dengan strategi pembelajaran. Dengan semakin baik persepsi mahasiswa terhadap lingkungan pembelajaran, mahasiswa lebih menggunakan pendekatan mendalam

Tabel 6. Hubungan persepsi terhadap lingkungan pembelajaran dengan strategi pembelajaran mahasiswa PSPD UNJA

\begin{tabular}{|c|c|c|c|c|c|}
\hline \multirow[t]{2}{*}{$\begin{array}{l}\text { Persepsi terhadap lingkungan } \\
\text { pembelajaran }\end{array}$} & \multicolumn{2}{|c|}{$\begin{array}{l}\text { Pendekatan } \\
\text { Dangkal }\end{array}$} & \multicolumn{2}{|c|}{$\begin{array}{l}\text { Pendekatan } \\
\text { Mendalam }\end{array}$} & \multirow[t]{2}{*}{ p } \\
\hline & $\mathrm{n}$ & $\%$ & $\mathrm{n}$ & $\%$ & \\
\hline Terdapat masalah (51-100) & 7 & 63,6 & 4 & 36,4 & 0,001 \\
\hline $\begin{array}{l}\text { Lebih banyak hal positif daripada } \\
\text { negatif }(101-150)\end{array}$ & 65 & 38,2 & 105 & 61,8 & \\
\hline $\begin{array}{l}\text { Sangat memuaskan } \\
(151-200)\end{array}$ & 1 & 5,9 & 16 & 94,1 & \\
\hline
\end{tabular}


Tabel 7 menunjukkan untuk kategori persepsi mahasiswa terhadap proses pembelajaran, pengajar, pencapaian akademik pribadi dan atmosfer pribadi didapatkan nilai $p<0,05$, sehingga dapat disimpulkan adanya hubungan antara persepsi mahasiswa terhadap proses pembelajaran, pengajar, pencapaian akademik pribadi, dan atmosfer akademik dengan strategi pembelajaran mahasiswa. Berdasarkan hasil uji bivariat setiap kategori, persepsi terhadap pencapaian akademik pribadi mendapatkan nilai $\mathrm{p}<0.001$, artinya persepsi tersebut paling berpengaruh terhadap strategi pembelajaran mahasiswa.

Untuk kategori persepsi terhadap kehidupan sosial, didapatkan nilai $\mathrm{p}=0,052(\mathrm{p}>0,05)$ hal ini menunjukkan tidak terdapat hubungan antara persepsi terhadap kehidupan sosial dengan strategi pembelajaran mahasiswa, tetapi dapat dilihat adanya kecenderungan, semakin baik persepsi mahasiswa terhadap kehidupan sosialnya, mahasiswa akan cenderung lebih menggunakan pendekatan mendalam dalam pembelajarannya.

Tabel 7. Hubungan kategori persepsi mahasiswa terhadap lingkungan pembelajaran dengan strategi pembelajaran mahasiswa

\begin{tabular}{|c|c|c|c|c|c|}
\hline \multirow[t]{2}{*}{ Kategori } & \multicolumn{2}{|c|}{$\begin{array}{l}\text { Pendekatan } \\
\text { Dangkal }\end{array}$} & \multicolumn{2}{|c|}{$\begin{array}{l}\text { Pendekatan } \\
\text { Mendalam }\end{array}$} & \multirow[t]{2}{*}{$\mathrm{p}$} \\
\hline & $\mathrm{n}$ & $\%$ & $\mathrm{n}$ & $\%$ & \\
\hline \multicolumn{6}{|c|}{ Persepsi terhadap Proses pembelajaran } \\
\hline Negatif $(13-24)$ & 7 & 58,3 & 5 & 41,7 & 0,001 \\
\hline Positif $(25-36)$ & 64 & 39,8 & 97 & 60,2 & \\
\hline Sangat baik (37-48) & 2 & 8,0 & 23 & 92,0 & \\
\hline \multicolumn{6}{|l|}{ Persepsi terhadap Pengajar } \\
\hline Sangat buruk $(0-11)$ & 0 & 0,0 & 1 & 100,0 & 0,037 \\
\hline Memerlukan perhatian (12-22) & 7 & 77,8 & 2 & 22,2 & \\
\hline Baik (23-33) & 56 & 37,3 & 94 & 62,7 & \\
\hline Sangat baik (34-44) & 10 & 26,3 & 28 & 73,7 & \\
\hline \multicolumn{6}{|c|}{$\begin{array}{l}\text { Persepsi terhadap Pencapaian akademik } \\
\text { pribadi }\end{array}$} \\
\hline Negatif (9-16) & 9 & 81,8 & 2 & 18,2 & $<0,001$ \\
\hline Positif (17-24) & 63 & 36,8 & 108 & 63,2 & \\
\hline Percaya diri $(25-32)$ & 1 & 6,3 & 15 & 93,8 & \\
\hline \multicolumn{6}{|l|}{ Persepsi terhadap Atmosfer akademil } \\
\hline Memerlukan perubahan (13-24) & 23 & 54,8 & 19 & 45,2 & 0,001 \\
\hline Positif $(25-36)$ & 50 & 33,8 & 98 & 66,2 & \\
\hline Baik (37-48) & 0 & 0,0 & 8 & 100,0 & \\
\hline \multicolumn{6}{|l|}{ Persepsi terhadap Kehidupan sosial } \\
\hline Bukan tempat yang baik (8-14) & 12 & 52,2 & 11 & 47,8 & 0,052 \\
\hline Cukup baik (15-21) & 58 & 36,0 & 103 & 64,0 & \\
\hline Sangat baik (22-28) & 3 & 21,4 & 11 & 78,6 & \\
\hline
\end{tabular}

Hubungan Jenis Kelamin Mahasiswa dengan Persepsi Mahasiswa terhadap Lingkungan Pembelajaran PSPD UNJA dan Strategi Pembelajaran Mahasiswa

Dari tabel 8 didapatkan nilai $\mathrm{p}=>0,05$ hal ini menunjukkan tidak terdapatnya hubungan antara jenis kelamin dengan persepsi mahasiswa terhadap lingkungan pembelajaran dan strategi pembelajaran mahasiswa. 
Tabel 8. Hubungan jenis kelamin mahasiswa dengan persepsi terhadap lingkungan pembelajaran dan strategi pembelajaran mahasiswa

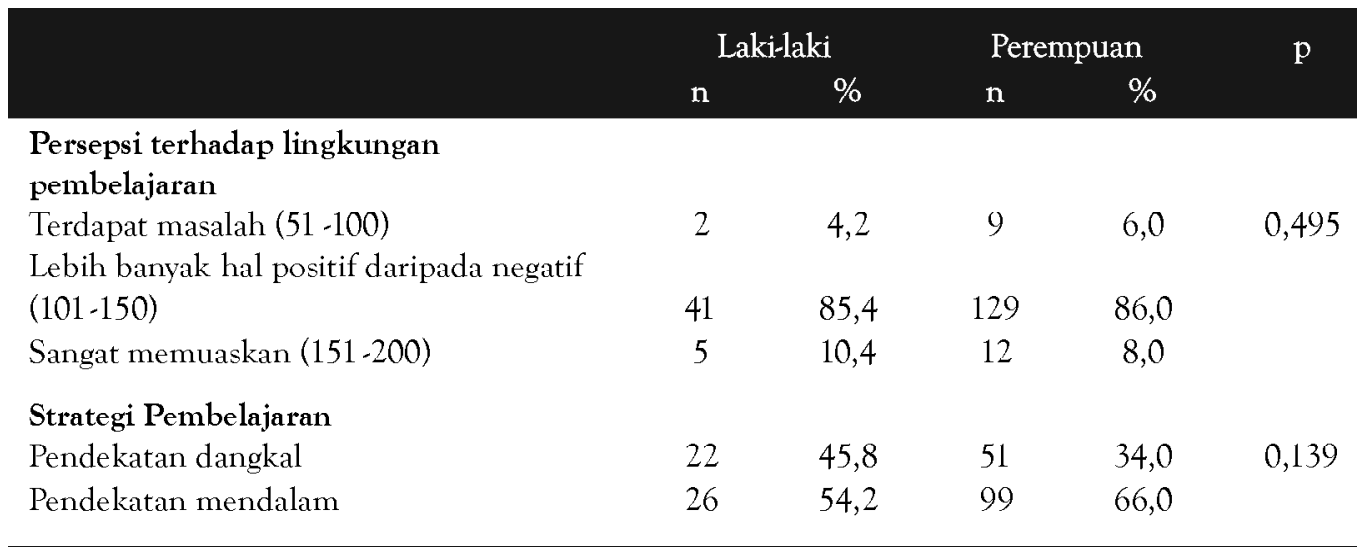

Hubungan tingkat akademik mahasiswa dengan persepsi mahasiswa terhadap lingkungan pembelajaran PSPD UNJA dan strategi pembelajaran mahasiswa PSPD UNJA

Dari tabel 9 untuk hubungan antara tingkat akademik dengan persepsi terhadap lingkungan pembelajaran didapatkan nilai $\mathrm{p}>0,05$ hal ini menunjukkan tidak terdapatnya hubungan antara tingkat akademik dengan persepsi terhadap lingkungan pembelajaran.
Untuk hubungan antara tingkat akademik dan strategi pembelajaran mahasiswa didapatkan nilai $p=0,011$, hal ini menunjukkan terdapatnya hubungan antara tingkat akademik dengan strategi pembelajaran mahasiswa. Dengan semakin tinggi tingkat akademik mahasiswa, mahasiswa lebih banyak menggunakan pendekatan dangkal.

Tabel 9. Hubungan tingkat akademik dengan persepsi terhadap lingkungan pembelajaran dan strategi pembalajaran mahasiswa

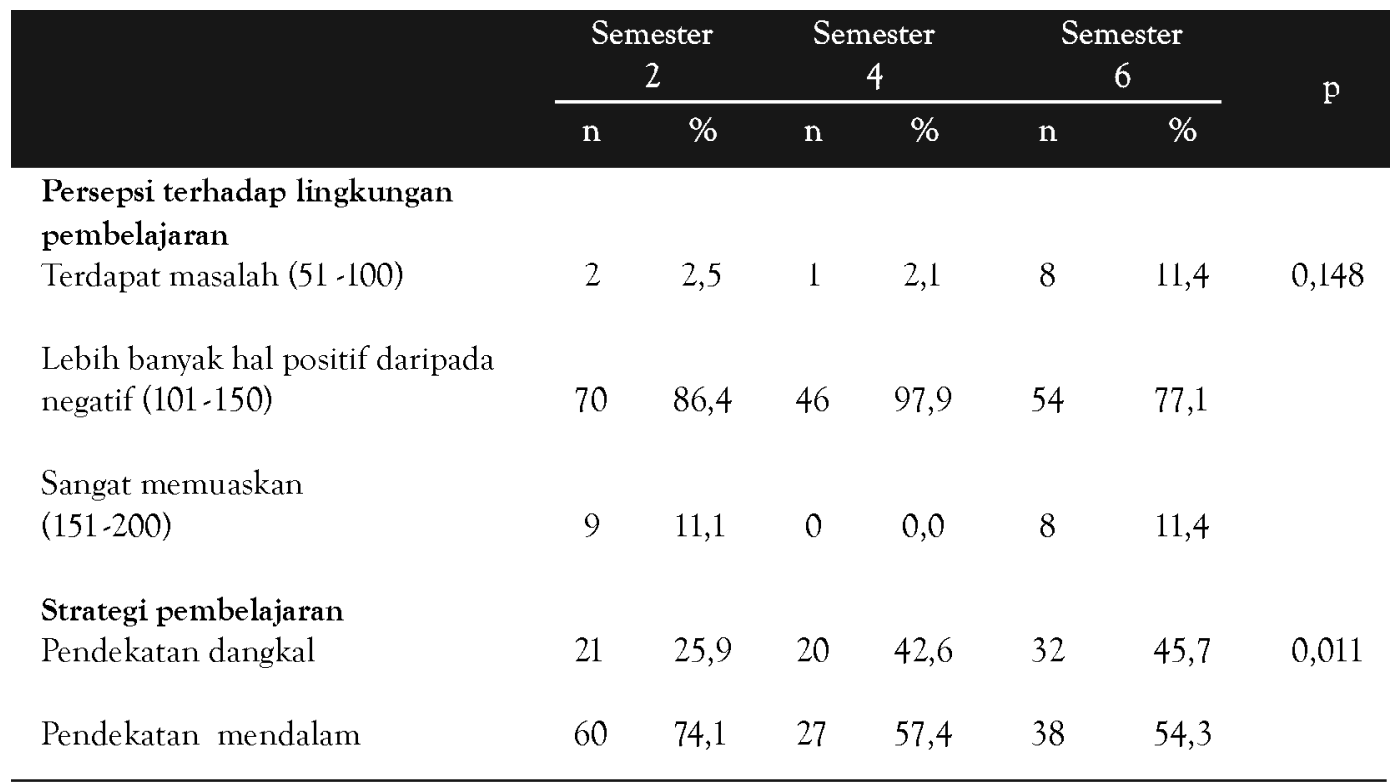




\section{PEMBAHASAN}

Persepsi mahasiswa terhadap lingkungan pembelajaran PSPD UNJA

Hasil penelitian menunjukkan bahwa lebih dari $80 \%$ mahasiswa PSPD UNJA memiliki persepsi positif terhadap lingkungan pembelajaran. Hasil yang sama juga didapatkan pada penelitian yang dilakukan sebelumnya pada mahasiswa kedokteran di Kasturba India dan yang dilakukan oleh Anisah (2010) di Jakarta.9,10 Persepsi positif terhadap lingkungan pembelajaran menunjukkan lingkungan pembelajaran PSPD UNJA telah sesuai dengan harapan mahasiswa.

\section{Kategori Persepsi Mahasiswa terhadap Lingkungan Pembelajaran}

Dari hasil penelitian terlihat bahwa kelima kategori persepsi terhadap lingkungan pembelajaran, sebagian besar $(74,7-86,4 \%)$ menyatakan hasil positif. Hasil ini menunjukkan rata-rata mahasiswa PSPD UNJA sudah cukup puas terhadap elemen lingkungan pembelajaran di PSPD UNJA. Hasil penelitian yang sama juga didapatkan pada penelitian yang dilakukan pada mahasiswa kedokteran Universitas Sam Ratulangi di Indonesia. ${ }^{11}$

Jumlah mahasiswa yang mempunyai persepsi kurang atau negatif terhadap kelima kategori sebanyak 4,5 21,2\% menunjukkan masih ada beberapa mahasiswa yang tidak puas terhadap elemen-elemen yang ada pada lingkungan pembelajaran PSPD UNJA. Persepsi negatif perlu dibahas agar dapat dilakukan perbaikan di masa datang, serta tidak menjadi gangguan yang berarti.

Pada kategori persepsi terhadap proses pembelajaran jawaban negatif paling banyak ditemukan pada pernyataan "kegiatan belajar mengajar terlalu menekankan pada pembelajaran mengenai informasi faktual". Sampai dengan sekarang hampir sebagian besar metode pengajaran di PSPD UNJA masih menggunakan metode kuliah satu arah yang hanya menekankan pada pemberian informasi faktual pada setiap blok pembelajaran.

Pada kategori persepsi terhadap staf pengajar, jawaban negatif paling banyak ditemukan pada pernyataan "staf pengajar menunjukkan kemarahan di dalam kelas". Pengalaman pembelajaran yang dialami mahasiswa dapat berbeda, jawaban negatif dari mahasiswa mungkin dapat disebabkan masih banyak staf pengajar PSPD UNJA yang belum memiliki kemampuan memfasilitasi kuliah dengan baik karena kurangnya pengalaman dalam kegiatan pengajaran. Staf pengajar PSPD UNJA terdiri dari staf pengajar tetap dan tidak tetap. Hampir sebagian staf pengajar tetap merupakan dokter-dokter muda yang masih baru dalam bidang pengajaran. Begitu juga dengan staf pengajar tidak tetap PSPD UNJA yang sebagian besar adalah dokter klinis yang berpengalaman dalam pelayanan kesehatan tetapi kurang pengalaman dalam pengajaran. Kurangnya pengalaman mungkin dapat menyebabkan ketidaksiapan pengajar dalam menghadapi kondisi tertentu pada situasi pembelajaran yang pada akhirnya menimbulkan kemarahan di dalam kelas. Saat ini PSPD UNJA masih jarang menyelenggara-kan seminar atau pelatihan yang bertujuan untuk pengembangan staf pengajar, sehingga staf pengajar jarang diberikan kesempatan untuk mengembangkan kemampuannya dalam memfasilitasi pengajaran.

Pernyataan "kemampuan pemecahan masalah berkembang dengan baik disini” mendapatkan jawaban negatif paling banyak pada kategori persepsi terhadap pencapaian akademik. Artinya, masih ada mahasiswa PSPD UNJA yang belum percaya diri terhadap kemampuan mereka dalam memecahkan suatu masalah. Salah satu metode pengajaran di PSPD UNJA adalah melalui diskusi tutorial, pada diskusi tutorial mahasiswa juga dilatih kemampuan untuk memecahkan suatu masalah. Apabila masih terdapat mahasiswa yang tidak percaya diri tehadap kemampuan tersebut, mungkin saja disebabkan proses diskusi yang tidak berjalan dengan baik, sehingga tidak semua mahasiswa terlatih dalam memecahkan suatu masalah.

Pernyataan "jadwal kegiatan belajar mengajar tersusun dengan baik" mendapatkan jawaban negatif terbanyak dari kategori persepsi terhadap atmosfer akademik. Jadwal dinilai mahasiswa tidak tersusun baik, mungkin disebabkan karena terjadi beberapa kali perubahan jadwal oleh staf pengajar karena berhalangan hadir dan pemberitahuan dilakukan secara mendadak, sehingga mahasiswa sudah hadir namun proses pembelajaran tidak dapat dilaksanakan. Para anggota staf pengajar perlu membudayakan mentaati jadwal dan memberi tahu bila berhalangan, melalui alat komunikasi yang sudah maju pada saat ini. Pada kategori persepsi terhadap kehidupan 
sosial, pernyataan "terdapat sistem dukungan yang baik bagi mahasiswa yang mengalami stres" mendapatkan jawaban negatif terbanyak. Sistem dukungan untuk mahasiswa yang mengalami stress memang belum tersedia di PSPD UNJA. PSPD UNJA belum mempunyai unit bimbingan konseling ataupun unit lain yang berfungsi untuk memberikan bantuan kepada mahasiswa.

\section{Strategi Pembelajaran Mahasiswa PSPD UNJA}

Hasil penelitian ini juga menunjukkan lebih dari 50\% mahasiswa PSPD UNJA menggunakan pendekatan mendalam dalam proses pembelajaran. Hasil yang sama juga didapatkan pada penelitian yang dilakukan oleh Mattick dkk. ${ }^{7}$ Pendidikan kedokteran diharapkan dapat mendorong mahasiswa untuk menggunakan pendekatan mendalam dalam pembelajarannya. ${ }^{12}$

Hubungan Persepsi terhadap Lingkungan Pembelajaran dengan Strategi Pembelajaran Mahasiswa Hasil penelitian ini menunjukkan adanya hubungan yang bermakna antara persepsi terhadap lingkungan pembelajaran dengan strategi pembelajaran mahasiswa. Dengan semakin baik persepsi mahasiswa terhadap lingkungan pembelajaran, mahasiswa lebih menggunakan pendekatan mendalam. Hasil penelitian yang sama juga ditemukan pada penelitian yang dilakukan oleh Parpala dkk. ${ }^{13}$ Parpala dkk menemukan bahwa mahasiswa yang memiliki persepsi yang baik terhadap situasi pembelajaran menerapkan pendekatan mendalam, sementara mahasiswa yang memiliki persepsi yang kurang baik terhadap situasi pembelajaran, menerapkan pendekatan dangkal. Penelitian yang dilakukan oleh Njhuis pada tahun 2006 juga menemukan bahwa persepsi positif terdapat lingkungan pembelajaran berhubungan dengan penggunaan pendekatan mendalam dan persepsi negatif berhubungan dengan penggunaan pendekatan dangkal. ${ }^{14}$

Penelitian ini juga menunjukkan adanya hubungan yang bermakna antara persepsi mahasiswa terhadap proses pembelajaran, pengajar, pencapaian akademik dan atmosfer akademik dengan strategi pembelajaran mahasiswa. Pada penelitian ini tidak didapatkan hubungan yang bermakna antara persepsi mahasiswa terhadap kehidupan sosial dengan strategi pembelajaran. Walaupun begitu tetap terdapat kecenderungan, semakin baik persepsi mahasiswa terhadap proses pembelajaran, pengajar, atmosfer akademik, pencapaian akademik pribadi dan kehidupan sosialnya, mahasiswa cenderung lebih menggunakan pendekatan mendalam. Berdasarkan hasil uji bivariat, persepsi terhadap pencapaian akademik pribadi paling berpengaruh terhadap strategi pembelajaran mahasiswa, tetapi untuk dapat memastikan persepsi yang paling berpengaruh terhadap strategi pembelajaran mahasiswa secara keseluruhan perlu dilakukan analisis lebih lanjut dengan menggunakan uji multivariat

Hal serupa dikemukakan Lizzio khususnya persepsi baik terhadap pengajaran mengarahkan pada pendekatan dalam, sementara persepsi buruk terhadap assessment dan beban belajar mengarahkan pada pendekatan dangkal. ${ }^{2}$ Menurut Ramsden penggunaan pendekatan mendalam dapat juga dipengaruhi oleh minat mahasiswa terhadap materi pembelajaran dan pengalaman pembelajaran mahasiswa pada lingkungan pendidikan sebelumnya yang juga mendorong penggunaan pendekatan mendalam. ${ }^{3}$

Hubungan Jenis Kelamin Mahasiswa dengan Persepsi Mahasiswa terhadap Lingkungan Pembelajaran dan Strategi Pembelajaran Mahasiswa

Penelitian ini juga menunjukkan bahwa tidak terdapat hubungan yang bermakna antara jenis kelamin dengan persepsi terhadap lingkungan pembelajaran.

Hasil yang berbeda didapatkan dari penelitian yang dilakukan oleh Mayya dkk, Al Hazimi dkk dan Zaini menunjukkan bahwa mahasiswa perempuan lebih merasa kurang puas terhadap lingkungan pembelajarannya. Perbedaan hasil penelitian ini dapat disebabkan adanya perbedaan kultur yang mempengaruhi sistem pendidikan dan menyebabkan terdapat perbedaan proses pembelajaran antara mahasiswa perempuan dan mahasiswa laki-laki. ${ }^{9},{ }^{15,16}$ Pada lingkungan pembelajaran di PSPD UNJA tidak terdapat pembedaan sistem pendidikan berdasarkan jenis kelamin, baik mahasiswa perempuan maupun mahasiswa laki-laki menjalani proses pembelajaran yang sama.

Penelitian menunjukkan tidak terdapat hubungan yang bermakna antara jenis kelamin dengan pemilihan strategi pembelajaran mahasiswa. Hal yang sama ditemukan pada penelitian yang dilakukan oleh Tomlison Clarke, Wilson dkk seperti yang dikutip oleh 
Jones. ${ }^{17} \mathrm{Hal}$ yang berbeda didapatkan pada penelitian dilakukan oleh Mattick dkk, pada penelitian ini jenis kelamin memiliki hubungan yang signifikan. Banyaknya hasil penelitian yang berbeda menyebabkan sampai dengan sekarang tidak dapat disimpulkan adakah hubungan antara jenis kelamin dengan pemilihan strategi pembelajaran mahasiswa. ${ }^{17}$

Hubungan Tingkat Akademik Mahasiswa dengan
Persepsi Mahasiswa terhadap Lingkungan
Pembelajaran dan Strategi Pembelajaran Mahasiswa Hasil penelitian ini juga menunjukkan tidak terdapat hubungan yang bermakna antara tingkat akademik mahasiswa dengan persepsi terhadap lingkungan pembelajaran. Hasil yang berbeda didapatkan dari penelitian oleh Zaini, menunjukkan bahwa persepsi terhadap lingkungan pembelajaran mempunyai hubungan dan dipengaruhi oleh tingkat akademik mahasiswa. ${ }^{16} \mathrm{Hal}$ ini dapat disebabkan adanya perbedaan kurikulum yang digunakan. Penelitian oleh Zaini dilaksanakan pada fakultas kedokteran yang menggunakan kurikulum tradisional. Pembelajaran tahun pertama sampai tahun ketiga diisi oleh perkuliahan yang bersifat teachercentred dan tahun keempat bersifat clinical teaching. Perubahan lingkungan pembelajaran yang mendadak dapat menyebabkan persepsi yang kurang baik terhadap lingkungan pembelajaran. Pada pembelajaran di PSPD UNJA tidak terdapat perubahan lingkungan pembelajaran di antara semester 2, 4 dan 6 dan dilaksanakan menggunakan strategi yang sama yaitu SPICES (Student centred, Problem based learning, Integrated approach, Community oriented, Early clinical exposure, Systematic).

Terdapat hubungan yang bermakna antara tingkat akademik dengan strategi pembelajaran mahasiswa. Dengan kecenderungan semakin tinggi tingkat akademik mahasiswa, mahasiswa lebih banyak menggunakan pendekatan dangkal. Hasil penelitian yang sama juga ditemukan pada penelitian yang dilakukan Samira dan penelitian yang dilakukan oleh Wilding dan Andrews. ${ }^{18,19}$

Kecenderungan penggunaan pendekatan dangkal ini dapat disebabkan beban belajar yang semakin berat seiring dengan peningkatan tahun akademik di PSPD UNJA. Sistem penilaian yang hanya bersifat recall knowledge dapat mendorong mahasiswa lebih cenderung menggunakan pendekatan dangkal dalam pembelajarannya. ${ }^{3,12}$ Sampai dengan sekarang ujian tulis yang dilaksanakan di PSPD UNJA masih banyak menggunakan soal yang bersifat recall knowledge.

\section{Keterbatasan Penelitian}

Keterbatasan penelitian ini adalah pada proses validasi kuesioner. Peneliti tidak melakukan proses validasi kuesioner yang digunakan pada penelitian ini pada mahasiswa PSPD UNJA. Hal ini disebabkan karena kuesioner DREEM dan R-2F-SPQ yang digunakan dalam penelitian ini telah melalui proses validasi dengan menggunakan mahasiswa fakultas kedokteran lain di Indonesia.

\section{KESIMPULAN}

Berdasarkan hasil penelitian dan pembahasan yang telah diuraikan sebelumnya, dapat diambil kesimpulan sebagai berikut:

1. Semakin baik persepsi mahasiswa terhadap lingkungan pembelajaran, mahasiswa lebih menggunakan pendekatan mendalam.

2. Delapan puluh persen mahasiswa PSPD UNJA memiliki persepsi positif terhadap lingkungan pembelajaran PSPD UNJA.

3. Lebih dari $50 \%$ mahasiswa PSPD UNJA menerapkan strategi pembelajaran pendekatan mendalam.

4. Tidak terdapat hubungan antara jenis kelamin dengan persepsi terhadap lingkungan pembelajaran ataupun strategi pembelajaran yang dipakai.

5. Adanya kecenderungan semakin tinggi tingkat akademik mahasiswa, mahasiswa lebih banyak menggunakan pendekatan dangkal.

\section{SARAN}

Berdasarkan hasil penelitian yang didapatkan, maka peneliti memberikan saran sebagai berikut:

1. Perlu dilakukan penelitian lebih lanjut untuk mengetahui faktor-faktor penyebab mahasiswa masih memiliki persepsi negatif terhadap lingkungan pembelajaran PSPD UNJA melalui proses depth interview. 
2. Perlu dilakukan usaha-usaha untuk meningkatkan dan mengoptimalisasi elemen-elemen yang terdapat di dalam lingkungan pembelajaran PSPD UNJA. Usaha tersebut antara lain perlu pengembangan staf pengajar melalui pelatihan dan seminar, peningkatan dan perbaikan perencanaan kegiatan pembelajaran di awal blok, penyediaan unit bimbingan dan konseling.

3. Perlu dilakukan usaha-usaha yang dapat mendorong mahasiswa menggunakan pendekatan mendalam. Salah satunya dapat dilakukan dengan cara pembagian beban belajar yang merata disetiap tingkat akademik dan penggunaan soal ujian tulis yang tidak bersifat recall knowledge.

\section{DAFTAR PUSTAKA}

1. Soemantri D. Measuring the educational environment in health professions studies: a systematic review to identify a valid and reliable instrument for use at the Faculty of Medicine University of Indonesia. Dissertation submitted in partial fulfilment for the master in medical education degree, University of Dundee, 2007.

2. Lizzio A, Wilson K, Simons, R. University student perception of the learning environment and academic outcome: implication for theory and practice. Studies in higher education, 2002; 27(1): 27-54.

3. Ramsden P. Learning to teach in higher education. New York: Routledge Falmer, 2006.

4. Duarte MA. Conception of learning and approach to learning in Portuguese student. Higher education, 2007; 54: 781-94.

5. Biggs J. Teaching for quality learning at University (2nd ed). Berkshire, UK: Open University Press, 2003

6. Diseth A, Martinsen O. Approach to learning, cognitive style, and motives as predictors of academic achievement. Educ. Psychology, 2003; 23(2): 195 209.

7. Mattick K, Dennis I, Bligh J. Approach to learning and studying inmedical student: Validation of a revised inventory and its relation to student characteristic and performance. Medical education, 2004; 38: 535-43

8. Cope C, Staehr L. Improving students' learning approaches through intervention in an information system learning environtment. Studies in higher education, 2005; 30 (2):181-197.

9. Mayya SS, Roff S. Student perception of an eductional environment: A comparison of academic achievers and under achievers at kasturba medical college India. Education for health, 2004; 17(3):28991.

10. Anisah. Hubungan antara persepsi mahasiswa FK UPN "Veteran" Jakarta terhadap lingkungan pembelajaran dengan prestasi belajar (magister thesis). Indonesia: Universitas Indonesia; 2011

11. Wowor PM et al. Persepsi mahasiswa terhadap atmosfer pendidikan di Fakultas Kedokteran Universitas Sam Ratulangi. Jurnal Perpipki 2011; 2: 1-8.

12. Reid WA, Duval E, Evans P. Can we influence medical students approach to learning? Medical teacher 2005; 27(5): 401-7.

13. Parpala A, Ylane SL, Komulainen L, Litmanen, T \& Hirsto L. Students' approach to learning and their expiriences of teaching learning environment. British journal of education psychology, 2010; 80: 269-82.

14. Nijhuis JFH. Learning strategies, students characteristic and their perceptions of the learning environment: An integrated study among business students. Disertasi, University of Maastricht. Available from: http://arno.unimaas.nl/show.cgi?fid $=6488$. [Accessed 25th February 2012].

15. Al- Hazimi A et.al. Educational environment in traditional and innovative medical cchools: A study in four undergraduate medical schools. Education for health 2004; 17 (2): 192-203.

16. Zaini R. Use of the Dundee ready educational environment measurement (DREEM) for curriculum needs analysis in the faculty of medicine \& medical sciences at umm al-Qura university, Saudi Arabia. Disertasi, University of Dundee. Available from: http://uqu.edu.sa/files2/tiny_mce/plugins/ $\mathrm{file} \mathrm{manager/files/4290228/4}$ zaini\%20Matser\%20Thesis\%202003\%20all.pdf [ Accessed 10th July 2012].

17. Jones C. Bigg's $3 \mathrm{P}$ model of learning: The role of personal characteristic and environmental influences on approach to learning. Disertasi. University of Griffith. Available from: http://www4.gu.edu.au: 8080/adt-root/uploads/approved/adt-QGU $20030304.092316 / \mathrm{public} / 02 \mathrm{Whole} . \mathrm{pdf}$. [Accessed 25th February 2012].

18. Samira J. Pengaruh kekuatan motivasi terhadap pendekatan pembelajaran mahasiswa preklinik semester genap Fakultas Kedokteran Universitas Trisakti (magister thesis). Indonesia: Universitas Indonesia; 2011.

19. Wilding J, Andrews B. Life Goals, approaches to studi and performance in an undergraduate cohort. Journal educational psychology 2006; 76: 171-82. 